\title{
PROGESTERONE: SITES OF ACTION IN INHIBITING OVULATION IN HAMSTERS
}

\author{
A. P. LABHSETWAR* \\ Worcester Foundation for Experimental Biology, \\ Shrewsbury, Massachusetts 01545, U.S.A.
}

(Received 15th August 1974)

\begin{abstract}
Summary. A single subcutaneous injection of progesterone $(0.5 \mathrm{mg} /$ animal at 17.00 hours) on Day 3 of the cycle (Day $1=$ day of vaginal discharge) interfered with ovulation and external vaginal discharge in all the animals. Lower doses were only partly active. Intravenous administration of LH, FSH or their combination at 14.00 hours on Day 4 failed to restore ovulation in such animals, implying a direct action of the administered progesterone on the ovary. A large dose of oestradiol benzoate $(400 \mu \mathrm{g} /$ animal) also proved inactive suggesting that progesterone did not interfere with ovulation solely through antioestrogenic action. Depletion of the pituitary LH stores normally found in association with ovulation and the ovulatory peak of LH in plasma seen in control animals were not observed in the progesterone-treated hamsters suggesting a further action of progesterone at the pituitary-hypothalamic level in inhibiting ovulation. Administration of synthetic LRF (100 ng/animal, i.v.) on Day 4 to hamsters treated with progesterone caused an increase in plasma LH 15 min later which was comparable to the rise observed in control animals given a similar injection of LH-RF, implying lack of action of progesterone at the pituitary level. It is concluded that progesterone acts centrally, principally on the hypothalamus, and peripherally on the ovary to interfere with ovulation in hamsters. It is possible that the anovulatory state accompanying pregnancy results from these actions.
\end{abstract}

\section{INTRODUCTION}

Progesterone exerts both inhibitory and facilitatory effects on ovulation (for reviews see Rothchild, 1965; Labhsetwar, 1972a), but the precise site(s) of action in many species is not known. In the rat, progesterone appears to act not only at the hypothalamic (Redmond, 1968; Labhsetwar \& Bainbridge, 1971) and pituitary levels (Stevens, Spies, Hilliard \& Sawyer, 1970; Labhsetwar, 1971) but also at the ovarian level (Stevens et al., 1970; Labhsetwar, 1971) to interfere with spontaneous ovulation. Whether such multiple sites of action are also characteristic for the hamster is not known. This species has very regular oestrous cycles of 4 days. The day of ovulation is signalled by the appearance of external vaginal discharge. As in rats, there is a critical period on

* Present address: Division of Biology, Kansas State University, Manhattan, Kansas 66506, U.S.A. 
the day of pro-oestrus and ovulatory release of gonadotrophin is preceded by the positive feedback of oestrogens (Labhsetwar, 1972b). In the present study, we have explored the possible site(s) at which progesterone acts to interfere with ovulation in hamsters.

\section{MATERIALS AND METHODS}

Animals

Adult hamsters were purchased from a local dealer and kept under controlled environmental conditions (light from 06.00 to 20.00 hours, temperature 21 to $22^{\circ} \mathrm{C}$ ). They were observed daily for external vaginal discharge and the day on which this was observed was taken as Day 1 of the cycle. Day 4 of the cycle corresponded to the day of pro-oestrus and Day 3 to the day of dioestrus in 4-day cyclic rats. All treatments were given on Day 3 or Day 4 and animals were killed on the morning of the expected day of oestrus, i.e. Day 1.

\section{Progesterone}

Crystalline steroid obtained commercially was weighed and dissolved in ethanol or acetone. Corn oil was added to achieve the desired concentration, usually $2.5 \mathrm{mg} / \mathrm{ml}$. The solution was kept in a hot water-bath to evaporate ethanol or acetone.

\section{Treatments}

In cyclic hamsters, progesterone was administered as a single subcutaneous injection in $0.2 \mathrm{ml}$ oil at 17.00 hours on Day 3. Gonadotrophins were administered intravenously between 13.00 and 14.00 hours on the following day to restore ovulation. Ovine LH (NIH-LH-S-11), FSH (NIH-FSH-S-6) or synthetic LH-RF (A-41070, Gn-RH, Abbott Laboratories) were given in $0.5 \mathrm{ml}$ saline through a femoral vein under ether anaesthesia. Oestradiol benzoate was given subcutaneously in $0.2 \mathrm{ml}$ oil.

\section{Autopsy}

Animals were killed on the morning of expected day of oestrus, i.e. Day 1, or $40 \mathrm{hr}$ after injection of progesterone. Both oviducts were removed and eggs were counted by the technique described earlier (Rowlands, 1942; Labhsetwar, 1970a). In some experiments, peripheral plasma and anterior pituitary glands were saved for LH assay. The pituitary glands were pooled within each group and subsequently assayed for LH by the ovarian ascorbic acid depletion assay of Parlow (1961), as described earlier (Labhsetwar, 1970b). The plasma samples were individually assayed for LH by the radioimmunoassay method of Niswender, Midgley, Monroe \& Reichert (1968). The validity of this assay for the measurement of hamster LH has been demonstrated by Goldman \& Porter (1970).

\section{Minimum effective dose}

\section{RESULTS}

In order to determine the minimal dose capable of inhibiting ovulation in $100 \%$ of hamsters, graded doses of progesterone were administered subcutan- 
eously at 17.00 hours on Day 3 of the cycle (Table 1 ). A dose of $0.5 \mathrm{mg} /$ hamster (about $3 \mathrm{mg} / \mathrm{kg}$ ) consistently interfered with ovulation but lower doses proved only partly active in reducing the frequency and rate of ovulation. All doses of progesterone, regardless of their ability to block ovulation, inhibited the appearance of external vaginal discharge on the morning of autopsy. There was some decrease in the ovarian weight and a significant increase in the uterine weight in hamsters treated with either 0.25 or $0.5 \mathrm{mg}$ progesterone (Table 1).

Table 1. Effects of graded doses of progesterone administered subcutaneously at 17.00 hours on Day 3 of the cycle on ovulation in hamsters

\begin{tabular}{c|c|c|c|c|c}
\hline $\begin{array}{c}\text { Dose of } \\
\text { progesterone } \\
\text { (mg/hamster })\end{array}$ & $\begin{array}{c}\text { No. ovulating/ } \\
\text { no. treated } \\
(\%)\end{array}$ & $\begin{array}{c}\text { No. of oval } \\
\text { ovulating } \\
\text { hamster }\end{array}$ & $\begin{array}{c}\text { Ovarian } \\
w t \\
(\mathrm{mg})\end{array}$ & $\begin{array}{c}\text { Uterine } \\
w t \\
(\mathrm{mg})\end{array}$ & $\begin{array}{c}\text { No. showing } \\
\text { vaginal } \\
\text { discharge/ } \\
\text { no. treated }\end{array}$ \\
\hline 0 & $5 / 5(100)$ & $9 \cdot 5$ & $29 \cdot 6 \pm 2 \cdot 3$ & $287 \pm 7$ & $5 / 5$ \\
$0 \cdot 1$ & $3 / 5(60)$ & $4 \cdot 3$ & $25 \cdot 2 \pm 0.9$ & $294 \pm 9$ & $0 / 5$ \\
0.25 & $2 / 5(40)$ & $4 \cdot 0$ & $23 \cdot 6 \pm 1 \cdot 8$ & $387 \pm 21^{*}$ & $0 / 5$ \\
0.5 & $0 / 5(0)$ & 0 & $22 \cdot 7 \pm 1 \cdot 8$ & $374 \pm 17 *$ & $0 / 5$ \\
1.0 & $0 / 5(0)$ & 0 & $24.8 \pm 0 \cdot 2$ & $358 \pm 44$ & $0 / 5$ \\
\hline
\end{tabular}

Ovarian and uterine weights are expressed in terms of Means \pm S.E.M.

* $P<0.01$ when compared with controls.

\section{Pituitary LH content}

Both the concentration $(\mu \mathrm{g} / \mathrm{mg})$ and content $(\mu \mathrm{g} / \mathrm{gland})$ of $\mathrm{LH}$ were significantly $(P<0.05)$ increased in hamsters given an ovulation-inhibiting dose of progesterone late on Day 3 and killed on the morning of Day 1 when compared to values in control hamsters killed at the same stage of the cycle (Exp. 1, Table 2). This suggests that depletion of LH stores which normally occurs in association with ovulation was prevented by progesterone. Pituitary LH stores also increased following daily administration of progesterone from Day 2 of the cycle for 10 days ( $4 \mathrm{mg} /$ day, subcutaneously in oil) when compared with those on Day 2 (Exps 2 and 3). The rise observed was comparable to that found during pregnancy (Exp. 4, Table 2). When progesterone was given for 10 days beginning on the day of ovariectomy, the increase in pituitary LH stores which followed ovariectomy in the controls was not prevented by the progesterone treatment (Exp. 5, Table 2).

\section{Plasma LH}

Plasma LH showed an ovulatory peak between 16.00 and 18.00 hours on Day 4 of the cycle but such a peak was not seen in animals pretreated with a dose of progesterone which inhibited ovulation. In these animals, the plasma LH averaged $38 \pm 5 \mathrm{ng}$ which was not significantly lower than the basal level found on Day 3 of the cycle in hamsters killed between 16.00 and 18.00 hours (Table 3).

\section{Restoration of ovulation}

Ovulation inhibited by progesterone could not be restored by an intravenous injection of $\mathrm{LH}$ given at 14.00 hours on Day 4 of the cycle to simulate 


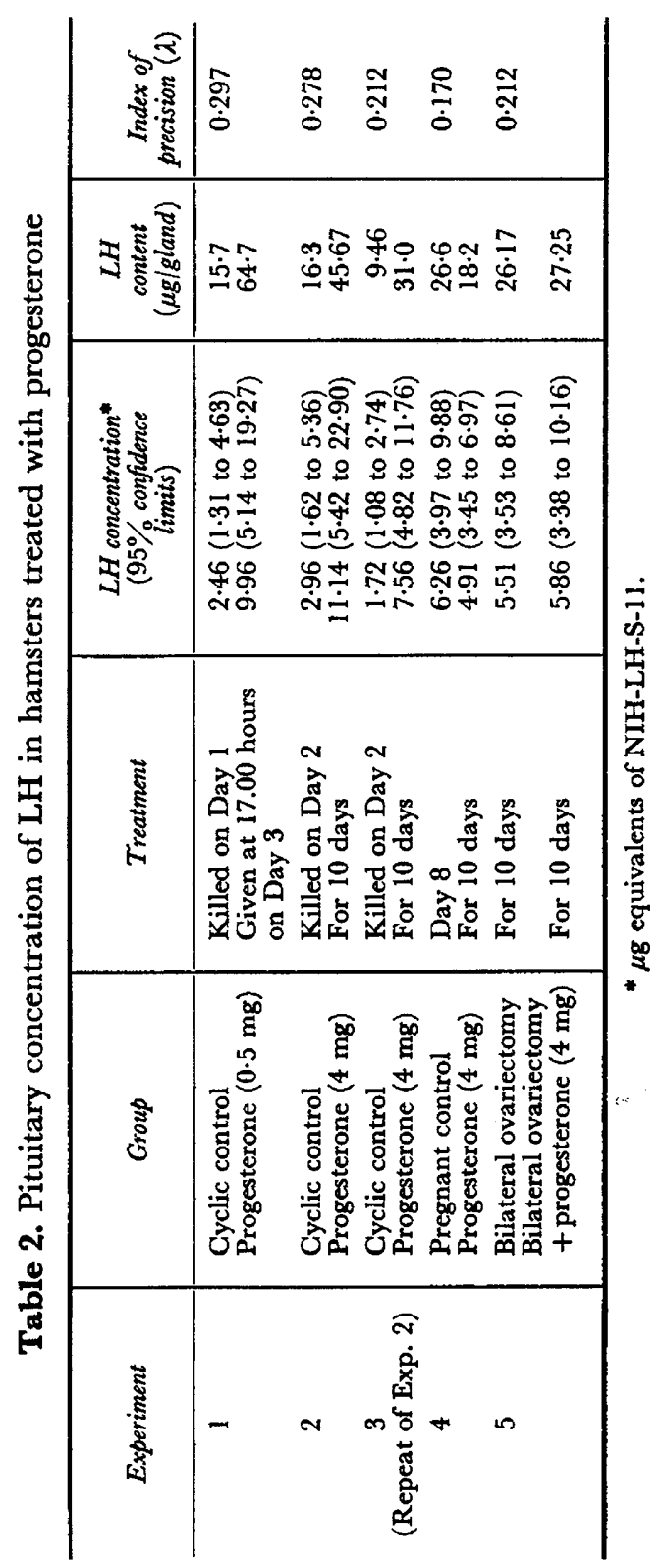


an endogenous LH surge. A 5- $\mu$ g dose was completely inactive, but increasing the dose to $25 \mu \mathrm{g} /$ animal evoked ovulation in three out of four hamsters although the ovulation rate was still subnormal (Exp. 1, Table 4). A similar administration of two different doses of FSH given alone or in combination with LH was also relatively inactive in restoring ovulation (Exp. 2). Injection of HCG restored ovulation in a proportion of animals $(60 \%)$ but the ovulation rate was still subnormal. A very high dose of oestradiol benzoate given subcutaneously at the same time as progesterone on Day 3 was also found to be inactive in restoring ovulation, but oestrogen alone, while not affecting the incidence of ovulation, did reduce the ovulation rate.

Table 3. Effect of a single subcutaneous injection of progesterone $(0.5 \mathrm{mg} / \mathrm{animal}$ given at 17.00 hours on the day before prooestrus) on the plasma LH at autopsy between 16.00 and 18.00 hours on Day 4 of the cycle

\begin{tabular}{l|c|c}
\hline \multicolumn{1}{c|}{ Group } & $\begin{array}{c}\text { No. of } \\
\text { animals }\end{array}$ & $\begin{array}{c}\text { Plasma } \\
\text { LH } \\
\text { (Mean } \pm \text { S.E. })\end{array}$ \\
\hline $\begin{array}{l}\text { Pro-oestrous control } \\
\text { Dioestrous control } \dagger \\
\text { Progesterone-treated }\end{array}$ & 5 & $717 \pm 135$ \\
\hline
\end{tabular}

***P$<0.001$ when compared with pro-oestrous controls.

$\dagger$ Killed between 16.00 and 18.00 hours on Day 3 of the cycle.

$\ddagger$ ng equivalents of LER $1213 \mathrm{~A} / \mathrm{ml}$.

$\$$ Not significantly different from dioestrous controls.

Effects of $L H-R F$ on $L H$ release in hamsters treated with progesterone

The direct action of progesterone on the anterior pituitary in interfering with ovulation was tested by studying pituitary sensitivity to exogenous LHRF given intravenously between 13.00 and 14.00 hours on Day 4 (Table 5). A single injection of synthetic LH-RF (100 ng/animal) caused a 15-fold increase in plasma $\mathrm{LH}$ in control animals examined 15 min later. A rise of approximately the same magnitude was observed in hamsters injected with $0.5 \mathrm{mg}$ progesterone late on Day 3 and given the same dose of LH-RF on the following day $(P<0.05)$. Thus the response of the pituitary to exogenous LH-RF appeared unimpaired by treatment with progesterone.

Induction of ovulation in hamsters under the prolonged influence of endogenous and exogenous progesterone

Since ovulation blocked by a single injection of progesterone could not be restored by gonadotrophins, it was of interest to examine ovarian response to the ovulatory action of HCG following prolonged exposure to either endogenous or exogenous progesterone. A single subcutaneous injection of HCG on Day 7 followed by autopsy on Day 8 of pregnancy revealed that all hamsters had ovulated but that the ovulation rate was subnormal (Group 2, Table 6); 


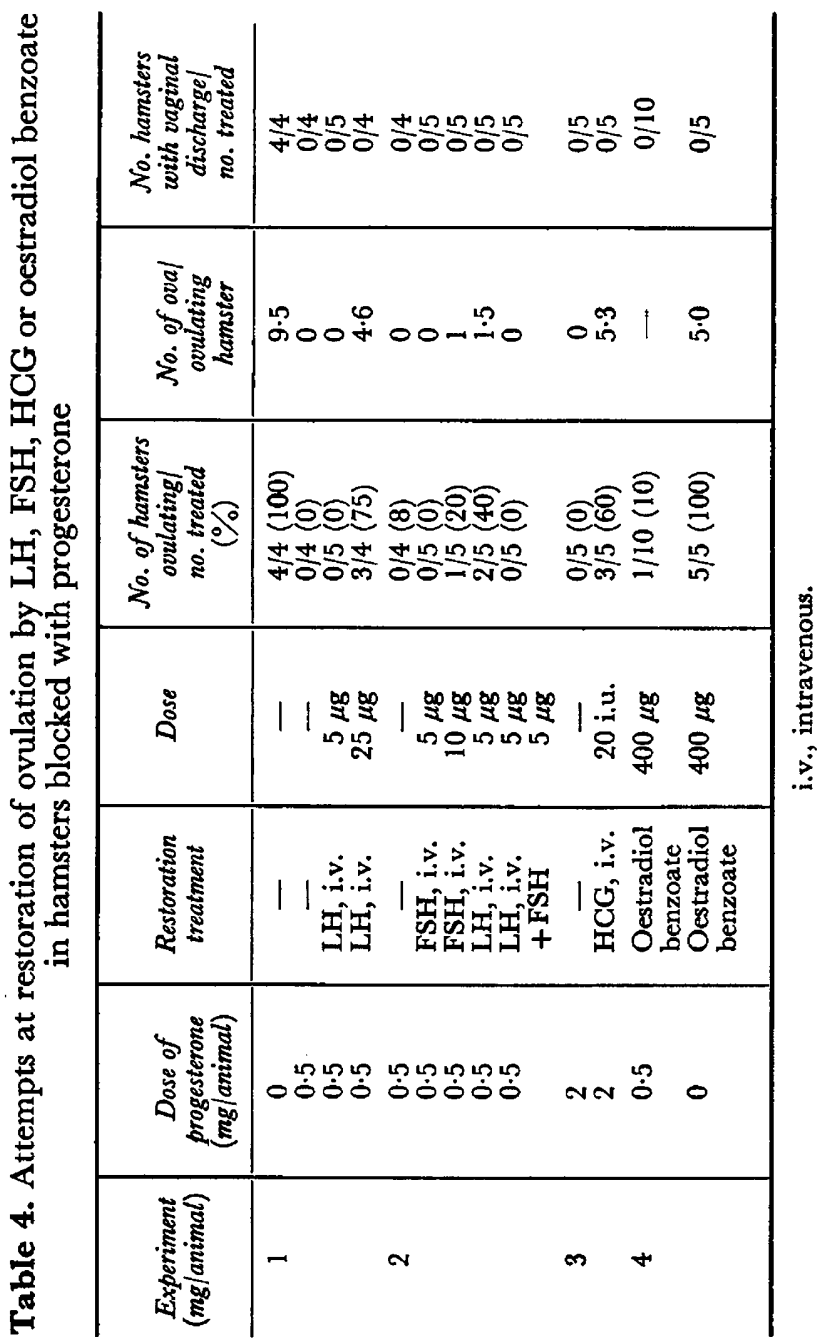


essentially similar results were obtained in pseudopregnant hamsters (Group 3). When exogenous progesterone was given for 7 (Group 4) or 10 days (Group 5) beginning on Day 2 of the cycle, the incidence of ovulation was quite high but the ovulation rate was still below normal, particularly following exposure for 10 days $(P<0 \cdot 05)$. When HCG was given on Day 2 of the cycle and hamsters were killed on the following day, i.e. 2 full days before the expected day of ovulation, the gonadotrophin failed to evoke premature ovulation (Group 6).

Table 5. Response of hamster pituitary to synthetic LH-RF in control and progesterone-treated hamsters on Day 4 of the cycle

\begin{tabular}{l|c|c}
\hline \multicolumn{1}{c|}{ Group } & $\begin{array}{c}\text { No. of } \\
\text { hamsters }\end{array}$ & $\begin{array}{c}\text { Plasma LH } \\
\text { (ng LER 1213A/ml) } \\
(\text { Mean } \pm \text { S.E. })\end{array}$ \\
\hline 1. Control & 4 & $18 \cdot 9 \pm 5 \cdot 0$ \\
2. Control +LH-RF (100 ng)* & 5 & $886 \cdot 2 \pm 174 \cdot 2$ \\
3. Progesterone (0.5 mg) $\dagger$ & 4 & $38 \cdot 6 \pm 6 \cdot 4+$ \\
4. Progesteronet+LH-RF (100 ng)* & 4 & $567 \cdot 6 \pm 62 \cdot 6 \$$ \\
\hline
\end{tabular}

* Given intravenously between 13.00 and 14.00 hours on Day 4 .

† Given subcutaneously at 17.00 hours on Day 3. Control animals in Groups 1 and 2 received only $0.2 \mathrm{ml}$ oil at this time.

$\ddagger$ Not significantly different from Group 1 .

$\$$ Not significantly different from Group 2 .

Table 6. Ovulation in progesterone-treated hamsters given HCG (20 i.u.) subcutaneously $24 \mathrm{hr}$ before the day of autopsy

\begin{tabular}{l|c|c}
\hline \multicolumn{1}{c|}{ Group } & $\begin{array}{c}\text { No. of hamsters } \\
\text { ovulating/ } \\
\text { no treated }\end{array}$ & $\begin{array}{c}\text { No. of oval } \\
\text { ouulating } \\
\text { hamster } \\
\text { (Mean S.E.) }\end{array}$ \\
\hline 1. Gyclic control, killed on Day 1 & $5 / 5$ & $12 \cdot 0 \pm 1 \cdot 0$ \\
2. Pregnant control, Day 8 & $4 / 4$ & $6 \cdot 25 \pm 1 \cdot 25$ \\
3. Pseudopregnant control, Day 8 & $4 / 4$ & $5 \cdot 76 \pm 1 \cdot 80$ \\
4. Progesterone, 4 mg for 7 days & $8 / 8$ & $7 \cdot 87 \pm 1 \cdot 77$ \\
5. Progesterone, 4 mg for 10 days & $7 / 8$ & $6 \cdot 57 \pm 1 \cdot 36$ \\
6. Cyclic control, killed on Day 3, HCG given on Day 2 & $2 / 8$ & $5 \cdot 0 \pm 1 \cdot 0$ \\
\hline
\end{tabular}

\section{Effects of prolonged administration of progesterone on ovaries}

In one experiment, progesterone was administered daily for 10 days (4 $\mathrm{mg} /$ day, subcutaneously in arachis oil) beginning on Day 3 of the cycle. The control animals received the vehicle only. Treatment with progesterone completely blocked external vaginal discharge during the course of the experiment but control animals showed discharge every 4 days. Microscopically, the ovaries were seen to lack corpora lutea; many follicles were atretric and the interstitium was atrophic. Vesicular follicles which appeared to be as large as those in the controls were, however, still present in the ovaries of the treated hamsters. 


\section{DISCUSSION}

As in the rat, there is a critical period on the afternoon of Day 4 of the cycle in the hamster (Greenwald, 1971). Secretion of progesterone is minimal in the afternoon of Day 3 and the morning of Day 4 and does not rise until after the ovulatory release of LH (Lukaszewska \& Greenwald, 1970; Leavitt \& Blaha, 1970; Labhsetwar, Joshi \& Watson, 1973). We selected the afternoon of Day 3 as the best time for administration of progesterone on the basis of an earlier study in which we found that an increased secretion of oestrogen for the positive feedback for ovulation in hamsters is initiated on the afternoon of this day (Labhsetwar, 1972b; Labhsetwar et al., 1973). When compared with rats, hamsters appear to be less sensitive to the inhibitory effects of progesterone as a $0.5-\mathrm{mg}$ dose (approx. $4.0 \mathrm{mg} / \mathrm{kg}$ ) was required to interfere with ovulation. Less than $2.5 \mathrm{mg} / \mathrm{kg}$ were required in rats (Labhsetwar \& Bainbridge, 1971) when given at a comparable stage of the cycle. While, in our study, a minimum of $500 \mu \mathrm{g}$ progesterone was required, Goldman, Mahesh \& Porter (1971) reported inhibition of ovulation in hamsters with only $50 \mu \mathrm{g}$ steroid given at the same stage of the cycle. We are unable to account for this tenfold difference in sensitivity as in our study even a 100- $\mu$ g dose was only partly active (Table 1).

Interference with ovulation by progesterone was associated with higher pituitary LH stores (Table 2) and a lack of ovulatory surge of LH in the plasma (Table 3) suggesting that the ovulatory release of LH was blocked by progesterone. This implies a central action of the steroid either on the pituitary and/or the hypothalamus. The fact that administration of synthetic LH-RF evoked release of LH from the pituitary (Table 5) suggests that the inability of the pituitary to release its ovulatory quantum of $\mathrm{LH}$ was not due to a refractory condition of the gland but probably because of interference by progesterone with the release of LH-RF from the hypothalamus, implying a neural site of action of progesterone. A similar site of action has been found in rats (Redmond, 1968; Labhsetwar \& Bainbridge, 1971) and rabbits (Spies, Stevens, Hilliard \& Sawyer, 1969). The conclusion that progesterone does not act directly on the pituitary in hamsters must, however, be regarded as tentative. This is because a threshold dose of LH-RF required to evoke ovulatory release of LH in the normal animal is not known. It is possible therefore, that the 100-ng dose used in the present study may be well above the minimum required and the excess may have overcome the inhibitory action of progesterone at the pituitary level. It is evident, however, that the action of progesterone on the pituitary is minor in the hamster, the major action apparently being exerted at the hypothalamic and ovarian levels to interfere with ovulation. Recently, Norman, Blake \& Sawyer (1973) have reported that the facilitatory action of progesterone on ovulation in hamsters is also exerted at the hypothalamic level. Thus progesterone exerts both facilitatory and inhibitory actions on ovulation in the hamster but, for the facilitatory type of action, progesterone was administered just before the critical period (Norman et al., 1973) on Day 4, i.e. after exposure of the central nervous system to oestrogens (Labhsetwar et al., 1973), while, for the latter type of action, progesterone was administered late on Day 3 (Table 1) when oestrogen secretion is initiated 
(Labhsetwar et al., 1973). In the rat also, prior exposure to oestrogens is essential for the manifestation of stimulatory effects of progesterone on ovulation (Brown-Grant, 1969).

In addition to acting centrally, progesterone also appears to act directly on the ovary. This view is based on the fact that exogenous $\mathrm{LH}$ given to simulate an endogenous LH surge failed to restore ovulation in hamsters which had received an inhibitory dose of progesterone (Table 4). The doses of $\mathrm{LH}$ used ( 5 and $25 \mu \mathrm{g} /$ animal, intravenously) were in fact several-fold higher than the minimal amount $(2.5 \mu \mathrm{g} /$ animal $)$ required to restore ovulation following hypophysectomy (Greenwald, 1971). In view of the earlier suggestion that FSH may be an important constituent of the ovulating hormone (Goldman \& Mahesh, 1968; Greenwald, 1971), this gonadotrophin was given either alone or in combination with LH but proved inactive in either instance (Table 4), despite the fact that both hormones were administered in doses higher than the minimum required in hypophysectomized hamsters (Greenwald, 1971). A large dose of $\mathrm{HCG}$, a gonadotrophin with a longer circulatory half-life than FSH or LH (Parlow \& Ward, 1961), restored the incidence of ovulation in cyclic animals given either single (Table 4) or multiple injections of progesterone (Table 6) but, in many instances, the ovulation rate was less than normal. Similar results were obtained in hamsters which had a prolonged exposure to endogenous progesterone, as during pregnancy (Table 6). It is evident from these data that progesterone acts directly on the ovary, rendering it either insensitive or less sensitive to the action of gonadotrophins. Ovarian action may induce atresia of large follicles (Greenwald, Keever \& Grady, 1967) or other more subtle changes such as binding of progesterone to gonadotrophin receptors in the ovary. Evidence in the rat also indicates an ovarian site of action of progesterone although its action at the ovarian level appears to be more intense in hamsters than in rats (Stevens et al., 1970; Labhsetwar, 1971). The possibility exists, however, that the ovarian site of action of progesterone may be more apparent than real. A single injection of the steroid at dioestrus may result in acutely depressed plasma gonadotrophin levels for several hours. The resulting withdrawal of gonadotrophin support may have adversely affected the ability of the ovarian follicles to respond to gonadotrophins. This possibility has not been excluded.

Progesterone is known to possess antioestrogenic activity (Dorfman, 1967). Since positive feedback of oestrogen plays an essential rôle in ovulation in the hamster (Labhsetwar, 1972b) and the ovarian secretion of oestrogens showed a marked rise on the afternoon of Day 3 when progesterone was injected in the present experiments, it is conceivable that progesterone blocked ovulation by antagonizing the positive feedback of oestrogens. The ability of oestradiol benzoate to restore ovulation was tested but the steroid proved inactive. In rats, exogenous oestrogen can restore ovulation, at least partly, under similar conditions (Labhsetwar, 1971).

In conclusion, it appears that progesterone in hamsters acts primarily on the hypothalamus and probably also on the ovary to interfere with ovulation. When compared with its action in rats, progesterone in hamsters appears to be more severe at the ovarian level and less marked at the pituitary level. 


\section{ACKNOWLEDGMENTS}

This work was initiated when the author was at the Pharmaceuticals Division, ICI Ltd, England. I thank Miss Rosemary Chester and Miss Patricial Maxwell for excellent technical assistance, Abbott Laboratories, Chicago, for donation of the synthetic decapeptide (Gn-RH), NIH for the gift of reference standards, Miss C. Roberson for determination of $\mathrm{LH}$ and $\mathrm{Dr} \mathrm{H}$. Joshi for his generous help. The author is also grateful to Dr Niswender, Dr Midgley and Dr Reichert for a gift of antigen-antibody for radioimmunoassay of LH.

\section{REFERENCES}

Brown-Grant, K. (1969) The induction of ovulation by ovarian steriods in the adult rat. F. Endocr. 43, 553-562.

Dorfman, R. I. (1967) The antiestrogenic and antiandrogenic activities of progesterone in the defense of a normal fetus. Anat. Rec. 157, 547-577.

Goldman, B. D. \& MAHEsh, V. B. (1968) Fluctuations in pituitary FSH during the ovulatory cycle in the rat and a possible role of FSH in the induction of ovulation. Endocrinology, 83, 97-106.

Goldman, B. D., Mareshi, V. B. \& Porter, J. C. (1971) The role of the ovary in control of cyclic LH release in the hamster, Mesocricetus auratus. Biol. Reprod. 4, 57-65.

Goldman, B. D. \& Porter, J. C. (1970) Serum LH levels in intact and castrated hamsters. Endocrinology, 87, 676-679.

Greenwald, G. S. (1971) Preovulatory changes in ovulating hormone in the cyclic hamster. Endocrinology, 88, 671-677.

Greenwald, G. S., Keever, J. E. \& Grady, K. L. (1967) Ovarian morphology and pituitary FSH and LH concentration in the pregnant and lactating hamster. Endocrinology, 80, 851-856.

LABHSETWAR, A. P. (1970a) Role of estrogens in ovulation: a study using the estrogen-antagonist, I.C.I. 46,474. Endocrinology, 87, 542-551.

LABHSETwAR, A. P. (1970b) Age-dependent changes in pituitary-gonadal relationships. III. Changes in pituitary LH and FSH levels in the male rat. F. Reprod. Fert. 21, 407-415.

LABHSETWAR, A. P. (1971) Exploration of site(s) of action of progesterone in inhibiting ovulation in rats. Biol. Reprod. 5, 115-122.

LABHSETWAR, A. P. (1972a) Pituitary gonadotrophic function (FSH and LH) in various reproductive states. Adv. Reprod. Physiol. 6, 97-183.

LABHSETWAR, A. P. (1972b) Role of estrogens in spontaneous ovulation: evidence for positive feedback in hamsters. Endocrinology, 90, 941-946.

LABHSETWAR, A. P. \& BAINBRIDGe, J. G. (1971) Inhibition of ovulation by intracranial implantation of progesterone in the 4-day cyclic rat. F. Reprod. Fert. 27, 445-449.

Labhsetwar, A. P., Joshi, H. S. \& Watson, D. (1973) Temporal relationship between estradiol, estrone and progesterone secretion in the ovarian venous blood and LH in the peripheral plasma of cyclic hamsters. Biol. Reprod. 8, 321-326.

Leavitr, W. W. \& BLAHA, G. C. (1970) Circulating progesterone levels in the golden hamster during the estrous cycle, pregnancy and lactation. Biol. Reprod. 3, 353-361.

Lukaszewska, J. H. \& Greenwaid, G. S. (1970) Progesterone levels in the cyclic and pregnant ham. ster. Endocrinology, 86, 1-9.

Niswender, G. D., Midgley, A. R., JR, Monroe, S. E. \& Reichert, L. L., JR (1968) Radioimmunoassay for rat luteinizing hormone with antiovine LH serum and ovine LH-131. Proc. Soc. exp. Biol. Med. 128, 807-811.

Norman, R. L., BLAKE, C. A. \& Sawyer, C. H. (1973) Evidence for neural sites of action of phenobarbital and progesterone on $\mathrm{LH}$ release in the hamster. Biol. Reprod. 8, 83-86.

Parlow, A. F. (1961) Bio-assay of pituitary luteinizing hormone by depletion of ovarian ascorbic acid. In Human Pituitary Gonadotropins, pp. 300-310. Ed. A. Albert. Thomas, Springfield, Illinois.

Parlow, A. F. \& WARD, D. N. (1961) Rate of disappearance of LH, PMS and HCG from plasma. In Human Pituitary Gonadotropins, pp. 204-209. Ed. A. Albert. Thomas, Springfield, Illinois.

REDMOND, W. C. (1968) Ovulatory response to brain stimulation and exogenous luteinizing hormone in progesterone-treated rats. Endocrinology, 83, 1013-1022.

RотнсніLD, I. (1965) Interrelations between progesterone and the ovary pituitary and central nervous system in the control of ovulation and the regulation of progesterone secretion. Vitams Horm. 23, 209-237.

RowLANDs, I. W. (1942) Collection of eggs from the Fallopian tube of the rat. Nature, Lond. 150, 267.

Stevens, K. R., Spies, H. G., Hilliard, J. \& Sawyer, C. H. (1970) Site(s) of action of progesterone in blocking ovulation in the rat. Endocrinology, 86, 970-975.

Spies, H. G., Stevens, K. R., Hilliard, J. \& Sawyer, G. H. (1969) The pituitary as a site of progesterone and chlormadinone blockade of ovulation in the rabbit. Endocrinology, 84, 277-284. 